Southern Illinois University Carbondale

OpenSIUC

Publications

Department of Zoology

$10-1-2003$

\title{
Aspidoderid Nematodes from Bolivian Armadillos, with the Description of a New Species of Lauroia (Heterakoidea: Aspidoderidae)
}

F Agustín Jiménez-Ruiz

agustinjz@siu.edu

Scott L Gardner

Follow this and additional works at: http://opensiuc.lib.siu.edu/zool_pubs

Published in the Journal of Parasitology, Vol. 92, No. 4 (2006): 847-854.

Copyright 2006, American Society of Parasitologists.

Used by permission.

\section{Recommended Citation}

Jiménez-Ruiz, F Agustín and Gardner, Scott L. "Aspidoderid Nematodes from Bolivian Armadillos, with the Description of a New Species of Lauroia (Heterakoidea: Aspidoderidae)." 89, No. 5 (Oct 2003).

This Article is brought to you for free and open access by the Department of Zoology at OpenSIUC. It has been accepted for inclusion in Publications by an authorized administrator of OpenSIUC. For more information, please contact opensiuc@lib.siu.edu. 


\title{
ASPIDODERID NEMATODES FROM BOLIVIAN ARMADILLOS, WITH THE DESCRIPTION OF A NEW SPECIES OF LAUROIA (HETERAKOIDEA: ASPIDODERIDAE)
}

\author{
F. Agustín Jiménez-Ruiz and Scott L. Gardner \\ The Harold W. Manter Laboratory of Parasitology, The University of Nebraska-Lincoln, Lincoln, Nebraska 68588-0514. e-mail: \\ fruiz@unlserve.unl.edu
}

\begin{abstract}
One nine-banded armadillo (Dasypus novemcinctus) and 1 yellow armadillo (Euphractus sexcinctus) were necropsied in the field during an expedition to collect parasites of mammals in Bolivia. A total of 205 Aspidodera binansata Railliet and Henry, 1913 (Heterakoidea: Aspidoderidae), and 40 specimens of Lauroia bolivari n. sp. (Heterakoidea: Aspidoderidae) were recovered from the cecum and large intestines of D. novemcinctus and E. sexcinctus. Aspidodera esperanzae Fujita et al., 1995, is proposed as a junior synonym of A. binansata based on the structure of the cordons on the hood. Lauroia bolivari $\mathrm{n}$. sp. has an undercut cephalic cap and unequal spicules. It differs from other species in the genus in the shape of the cephalic cap and from Lauroia travassosi Proença, 1938, in the relative proportion of the spicules. This is the first record of a member of Lauroia Proença, 1938, for Bolivia.
\end{abstract}

Nematodes of Aspidoderidae Skrjabin and Schikhobalova, 1947 (Ascaridida: Heterakoidea), occur in the cecum and large intestine of Neotropical mammals. The range of hosts for species in the family includes xenarthrans, didelphiomorphs, and hystricognath and sigmodontine rodents. Currently, the Aspidoderidae contains 16 species in 6 genera. Recognized subfamilies include the Aspidoderinae Skrjabin and Schikhobalova, 1947, and Lauroiinae Skrjabin and Schikhobalova, 1951, each composed of 8 species. So far, discussions on the taxonomy of the family are biased toward species included in Aspidoderinae (Proença, 1937; Freitas, 1956; Santos et al., 1990), whereas the Lauroiinae has not been studied in the same detail (Gomes and Pereira, 1970; Chabaud, 1978; Sutton et al., 1980). The diagnostic traits for both Lauroiinae and Aspidoderinae are the presence of cordons with recurrent branches for the latter (Fig. 1a) and the smooth and platelike surface of the hood for the former (Fig. 1b).

The geographic range for Aspidoderidae extends from central Argentina through the southeastern United States. Species in Aspidodera Railliet and Henry, 1912, occur across the entire geographic range of the family, and they have the widest host range, occurring in armadillos (Dasypodidae), anteaters (Myrmecophagidae), opossums (Didelphidae), water rats (Muridae), and pacas (Agoutidae). Apparently intratropical in distribution, Lauroia Proença, 1938, includes 4 species occurring exclusively in armadillos.

Despite several biotic surveys of Bolivia (Anderson, 1997), aspidoderid nematodes had been collected and reported infrequently from that country. Available records show that Aspidodera binansata Railliet and Henry, 1913, infects Tolypeutes matacus (Desmarest, 1804) in the lowlands, and Paraspidodera spp. occur in Ctenomys spp. on the Altiplano and other areas (Sprehn, 1932; Gardner, 1991).

In this article, we describe a new species of Lauroia Proença, 1938, and demonstrate that Aspidodera esperanzae Fujita, Abe, Oku, Sanabria, Inchaustti, and Kamiya, 1995, is a junior synonym of A. binansata.

\section{MATERIALS AND METHODS}

One specimen each of the long-nosed armadillo (Dasypus novemcinctus Linnaeus, 1758) and the yellow armadillo (Euphractus sexcinc-

Received 2 August 2002; revised 24 March 2003; accepted 24 March 2003. tus (Linnaeus, 1758)) were obtained from local hunters in the lowlands of Bolivia in the austral autumn of 2000. The long-nosed armadillo was captured alive and killed with chloroform. The yellow armadillo was killed by hunters in the field. The latter was collected at Estancia San Marcos $\left(15^{\circ} 53^{\prime} 34^{\prime \prime} \mathrm{S}, 63^{\circ} 11^{\prime} 20^{\prime \prime} \mathrm{W}\right)$ on 1 June and the former near Totaisal $\left(14^{\circ} 54^{\prime} 08^{\prime \prime} \mathrm{S}, 66^{\circ} 19^{\prime} 48^{\prime \prime} \mathrm{W} ; 198 \mathrm{~m}\right)$ on 22 May.

The ceca and large intestines were examined in our field laboratory, and separate samples of parasites were killed with glacial acetic acid, $70 \%$ ethanol, or $10 \%$ formalin and stored in $70 \%$ ethanol or $10 \%$ formalin. Some of the specimens collected alive were washed in saline solution and snap frozen in liquid nitrogen, transported in nitrogen to the Harold W. Manter Laboratory (HWML), and frozen permanently at $-80 \mathrm{C}$. Specimens were cleared using lactophenol and identified using published descriptions and by direct comparison with type specimens. Specimens prepared for scanning electron microscopy (SEM) were treated with osmium-thiocarbohydrazide-osmium-thiocarbohydrazideosmium, dehydrated, dried by critical point drying using $\mathrm{CO}_{2}$, and then coated with gold palladium.

Specimens examined were borrowed from the Colección Helmintologica del Instituto Oswaldo Cruz (CHIOC), Rio de Janeiro, Brazil; Colección Nacional de Helmintos (CNHE), Mexico City, Mexico; Collection of Parasitology of the School of Veterinary Medicine of the University of Hokkaido (CPSVM), Sapporo, Japan; and the United States National Parasite Collection (USNPC), Beltsville, Maryland. Species used for comparisons included Lauroia intermedia Caballero, 1955 (CNHE 2460); Lauroia travassosi Proença, 1938 (CHIOC 9644, 9712); Proencaia heterospiculata Gomes and Pereira, 1970 (CHIOC 30527); Ansiruptodera ansirupta (Proença, 1937) (CHIOC 9637, 29934); Aspidodera vazi Proença, 1937 (CHIOC 9641, 14086, 18354); A. binansata Railliet \& Henry, 1913 (CHIOC 8260, 9637, 9639, 9643, 18351); Aspidodera fasciata (Schneider, 1866) (CHIOC 4119, 11190; USNPC 8550, 59968; and CPSVM 2950); and A. esperanzae (CPSVM 2955, 2960).

Specimens were measured with the SigmaPro Image Analyzer (Albinger et al., 1995) attached to a Zeiss ${ }^{\mathbb{\pi m}}$ ultraphot microscope. Measurements are in micrometers. For each character the range is given first followed by sample mean and coefficient of variation in parentheses (Sokal and Rohlf, 1981). Drawings were made with a Wild microscope equipped with a drawing tube. Specimens prepared for SEM were exposed to a beam of $15 \mathrm{kV}$ on a Hitachi field S-3000.

\section{RESULTS}

We identified 2 species of aspidoderid nematodes occurring in both species of armadillos, 1 is a new species of the genus Lauroia and the other we identified as A. binansata.

\section{Aspidodera binansata Railliet \& Henry, 1913}

The worms appeared whitish in color in situ. The specimens display all diagnostic traits for the species, including the same number of branches or loops in the cordons, the general outline 


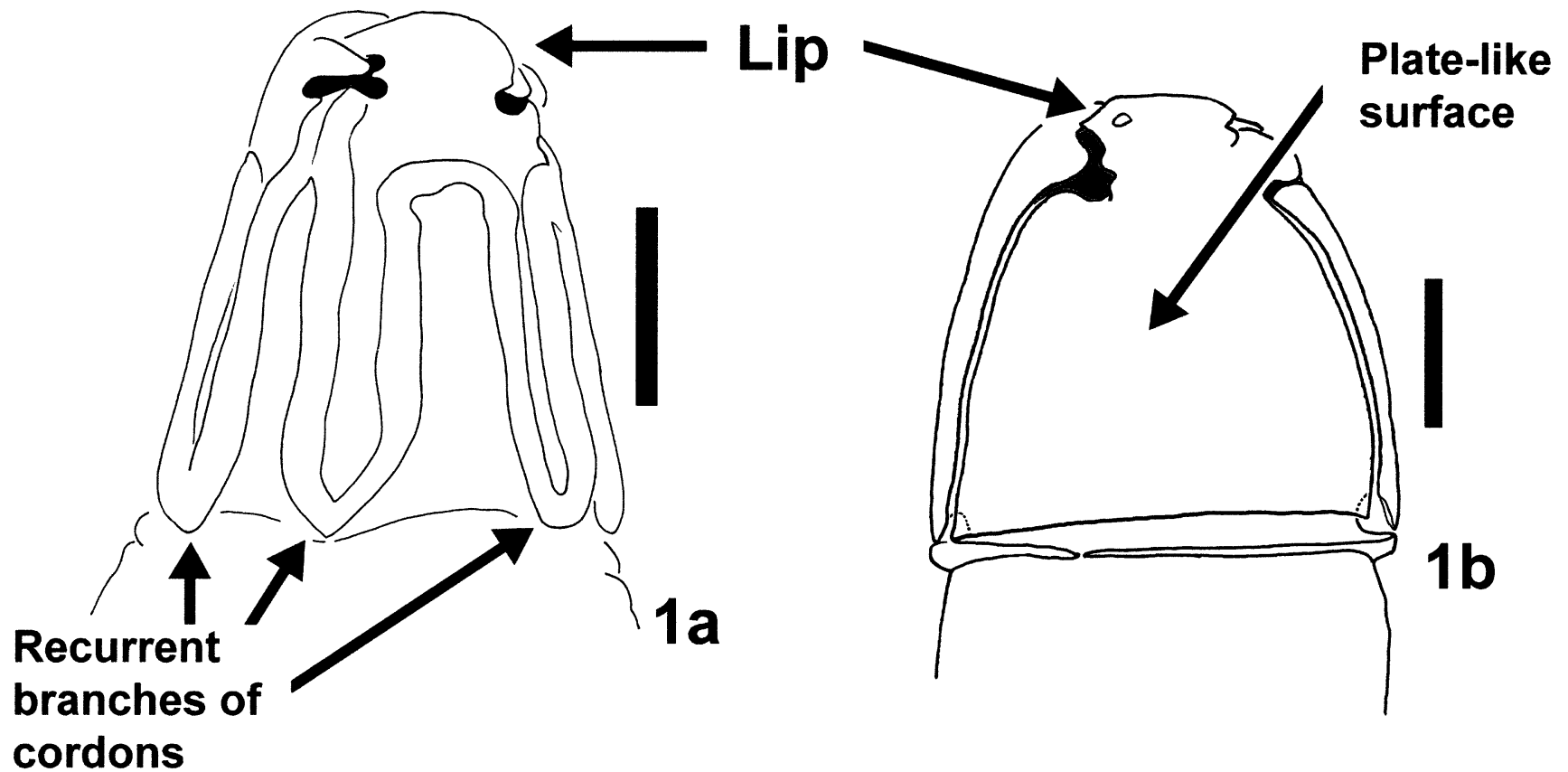

FIGURE 1. Comparison of the structure of the hood in Aspidideridae viewed in the right lip. a. Diagram of the hood of Aspidodera binansata $\delta$ showing the branches of the cordons. Bar $=50 \mu \mathrm{m}$. b. Diagram of the cephalic plate in Lauroia trinidadensis $\hat{\delta}$. Bar $=30 \mu \mathrm{m}$.
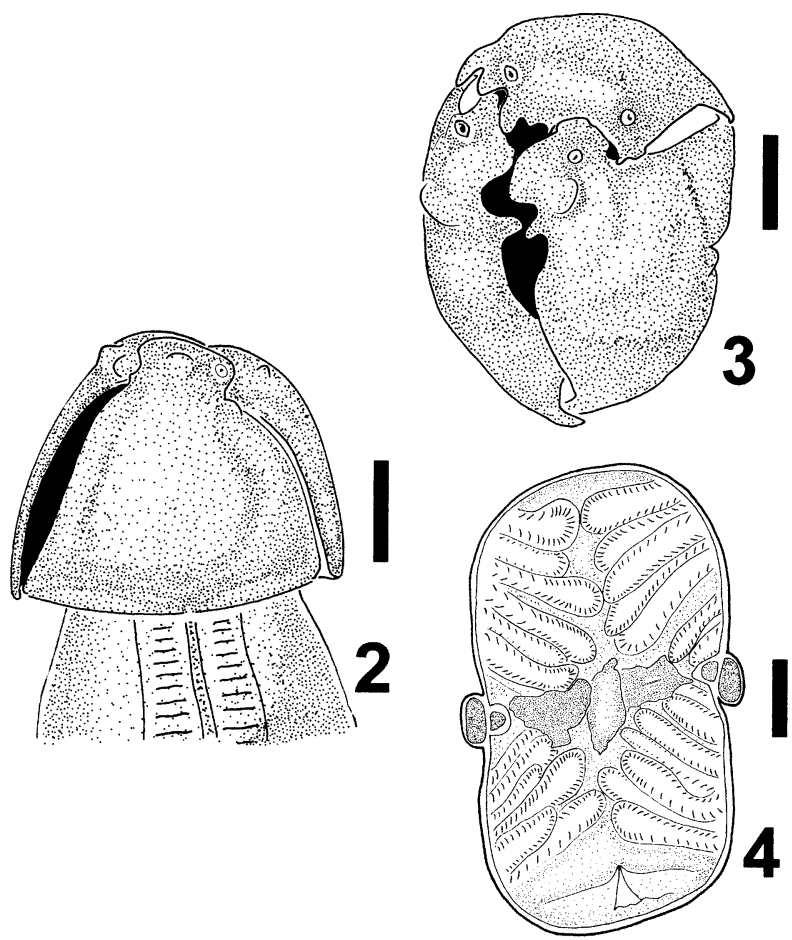

FiguRES 2-4. Lauroia bolivari n. sp. 2. Cephalic cap of a 9 showing the right lip; the appendix in the posterior most part of the cap is depicted. Bar $=30 \mu \mathrm{m}$. 3. Face view of a $\delta^{-}$; note the smaller proportional size of the dorsal lip. Bar $=20 \mu \mathrm{m}$. 4. Cross section of a $\delta^{\lambda}$ at midbody; note the rounded and thick lateral alae. Bar $=50 \mu \mathrm{m}$. of the spicules, and the number of papillae on the posterior rim of the genital sucker.

\section{Taxonomic summary}

Individuals collected: Dasypus novemcinctus harbored 173 worms and E. sexcinctus hosted 32.

Hosts: Dasypus novemcinctus Linnaeus, 1758, deposited at the Museum of Southwestern Biology (MSB) of the University of New Mexico catalog number MSB 99076, Division of Biological Materials, New Mexico, kryovoucher number NK102065. Euphractus sexcinctus (Linnaeus, 1758) deposited at MSB catalog number 99076, Division of Biological Materials, New Mexico, kryovoucher number NK102246.

Localities: Totaisal, Departamento del Beni, Bolivia, $14^{\circ} 54^{\prime} 08^{\prime \prime} \mathrm{S}, 66^{\circ} 19^{\prime} 48^{\prime \prime} \mathrm{W}$, elevation $198 \mathrm{~m}$ for $D$. novemcinctus.

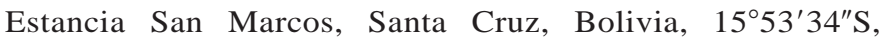
$63^{\circ} 11^{\prime} 20^{\prime \prime} \mathrm{W}$, for E. sexcinctus.

Specimens deposited: Specimens from D. novemcinctus deposited in HWML under accession numbers HWML16953, HWML16962, and HWML16963 and in CNHE under accession number 4572; specimens collected from E. sexcinctus are deposited under accession numbers HWML16954 and HWML16964.

Habitat: Attached to mucosa and in lumen of cecum and large intestine.

\section{DESCRIPTION}

\section{Lauroia bolivari n. sp.}

(Figs. 2-8, 11)

Twenty-two and five worms representing this species were recovered from $D$. novemcinctus and E. sexcinctus, respectively. 

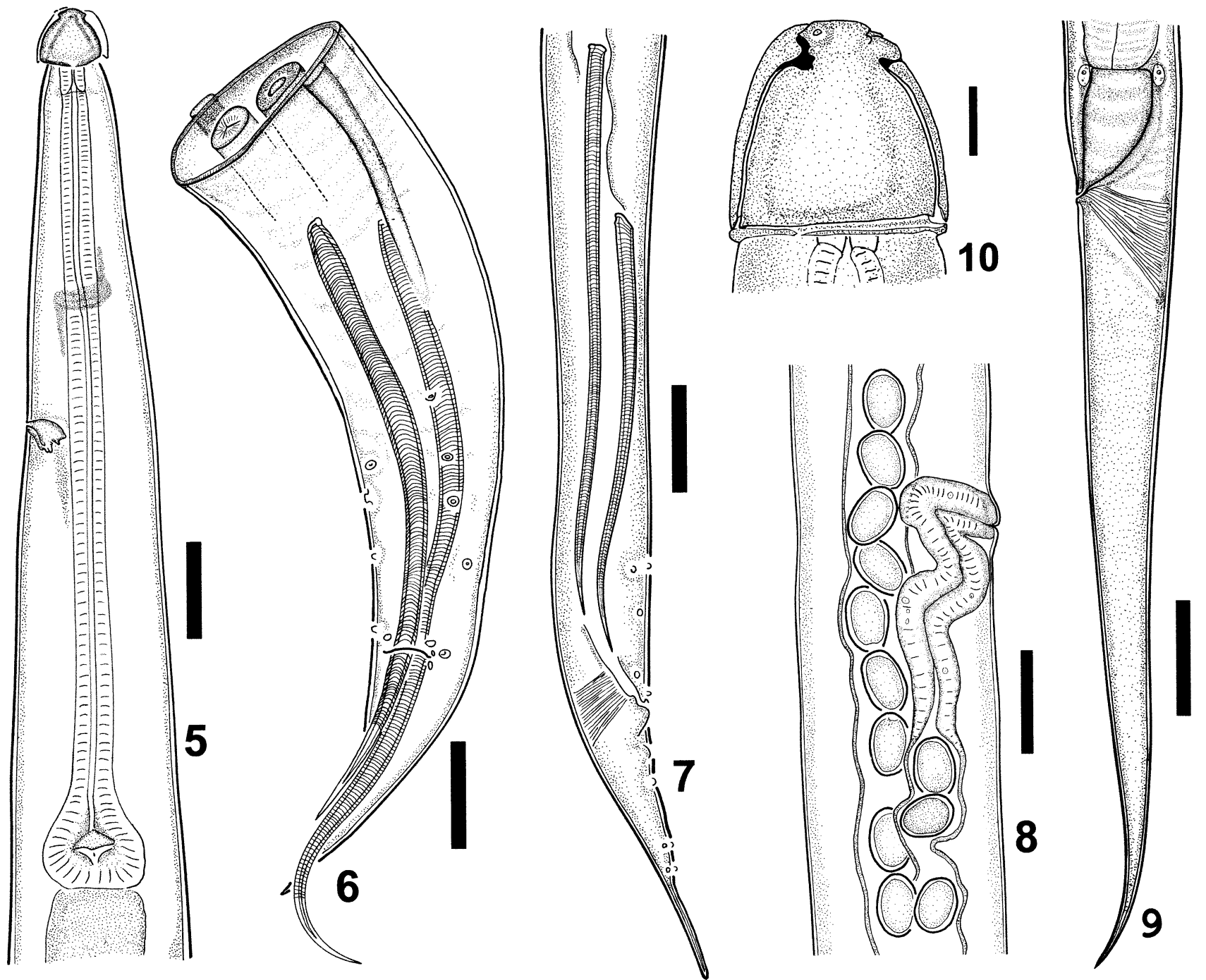

FiguRES 5-10. Lauroia bolivari n. sp. 5. Lateral view of the anterior end of a $\delta$ displaying the entire esophagus. Bar $=100 \mu \mathrm{m}$. 6. Caudal end of a $\hat{\delta}$ in ventral view showing arrangement of papillae. Bar $=100 \mu \mathrm{m}$. 7. Caudal end of a $\hat{\delta}$ in lateral view showing the unequal spicules. Bar $=100 \mu \mathrm{m}$. 8. Lateral view of the ovijector. Bar $=100 \mu \mathrm{m}$. 9. Lateral view of the tail of a $q$. Bar $=100 \mu \mathrm{m}$. 10. Cephalic cap of a $q$ of Lauroia trinidadensis, note the uniform groove running underneath the posterior margin of the cap. Bar $=30 \mu \mathrm{m}$.

General: Nemas with slender bodies, sharp tail, red when alive. Cuticular sheet extending posteriad and laterally covering each lip forming the cephalic cap (Fig. 2). Interlocking lobes, reduced. Dorsal lip smaller than lateroventral lips (Fig. 3). Two laterally located papillae on dorsal lip (Fig. 3). Each lateroventral lip with 2 papillae on dorsal side (Fig. 2). Lateral alae rounded and thick in transverse outline (Fig. 4). Alae from level of nerve ring to just before cloacal or anal opening (Figs. 5, 6). Spicules unequal (Figs. 6, 7), surface of spicules ornamented with transverse ridges.

Males: (Based on measurements of 13 specimens, unless otherwise indicated.) Body length 2,965-7,746, 6,014 (22\%); width at midbody $129-265,172(23 \%)$. Alae length $\mathrm{n}=3$, 3,942-5,037, 4,548 (13\%). Cephalic hood 45-70, 54 (16\%) long and 49-75, $60(13 \%)$ wide. Nerve ring $(\mathrm{n}=9)$ and excretory pore $(\mathrm{n}=11)$ located $172-289,231(16 \%)$ and $313-$ $427,375(10 \%)$ from anterior end, respectively. Stoma 13-24, 17 (19\%). Total length of esophagus including bulb 483-834,
$606(17 \%)$. Pharynx 44-83, 63 (16\%) long and 20-34, 25 (17\%) wide. Corpus 344-689, 509 (20\%) long and 28-55, 36 $(25 \%)$ wide at the level of nerve ring. Bulb of esophagus pyriform 71-145, 97 (28\%) long and 59-123, 84 (19\%) wide. Length of left spicule 291-613, $466(20 \%)$ and 11-32, 21 (26\%) width at calomus; length of right spicule 376-751, 601 $(19 \%)$ and $11-37,23(36 \%)$ width at calomus. There are 12 pairs of papillae, all subventral and sessile. Five precloacal pairs, 2 adcloacal pairs, 5 postcloacal pairs (Fig. 6). Ventral hole in the cuticule between the third pair of precloacal papillae, and a ventral bump immediately postcloacal. Tail 223-283, 260 (7\%).

Females: (Based on measurements of 14 individuals, unless otherwise stated.) Body length 5,169-8,119, 6,971 (13\%); width at level of vulva 135-296, 191 (22\%). Extension of alae $\mathrm{n}=8,4,290-7,063,5,945(14 \%)$. Nerve ring $(\mathrm{n}=11)$ and excretory pore $(\mathrm{n}=12) 174-290,243(12 \%)$ and 307-403, $355(10 \%)$, respectively, from anterior end. Cephalic cap 49- 
66, $58(8 \%)$ long and 53-68, $61(8 \%)$ wide. Stoma 15-23, 18 (14\%). Total length of esophagus 557-745, 657 (9\%). Pharynx $52-76,65$ (11\%) long by 18-26, 22 (13\%) wide. Corpus length 467-631, 564 (9\%) and width $\mathrm{n}=13,30-42,34$ (9\%). Bulb of esophagus 81-113, 93 (10\%) long and 69-125, 88 (17\%) wide. Vulva $(\mathrm{n}=13)$ located $1,819-2,844,2,431(13 \%)$ from anterior end; length of ovijector $\mathrm{n}=4,125-185,159(17 \%)$ (Fig. 8). Uteri contain nonembryonated eggs $\mathrm{n}=286,50-70$, $60(7 \%)$ by $31-44,37(6 \%)$. Tail $\mathrm{n}=12,530-688,627(8 \%)$ (Fig. 9).

\section{Taxonomic summary}

Type host: Dasypus novemcinctus Linnaeus, 1758 (symbiotype [Frey et al., 1992]), deposited at MSB catalog number MSB 99076, Division of Biological Materials, New Mexico, kryovoucher number NK102065.

Type locality: Totaisal, Departamento del Beni, Bolivia, $14^{\circ} 54^{\prime} 08^{\prime \prime} \mathrm{S}, 66^{\circ} 19^{\prime} 48^{\prime \prime} \mathrm{W}$, elevation $198 \mathrm{~m}$.

Other host: Euphractus sexcinctus (Linnaeus, 1758) deposited at MSB catalog number MSB 99077, Division of Biological Materials, New Mexico, kryovoucher number NK102246.

Locality: Estancia San Marcos, Santa Cruz, Bolivia, $15^{\circ} 53^{\prime} 34^{\prime \prime} \mathrm{S}, 63^{\circ} 11^{\prime} 20^{\prime \prime} \mathrm{W}$.

Specimens deposited: Holotype, male HWML16948. Allotype, female HWML16949; 20 paratypes HWML16950, vouchers HWML16951, HWML16952, and HWML16961.

Habitat: Attached to mucosa and in lumen of cecum and large intestine.

Etymology: The species is named after Simón Bolivar, leader of the South American War for Independence and first President of the Republic of Bolivia.

\section{Diagnosis}

Lauroia bolivari most closely resembles L. travassosi in the structure of the cephalic cap, extension of the lateral alae, and texture of spicules; however, in L. bolivari the right spicule is longer than the left spicule. Lauroia bolivari is different from Lauroia dasypi, L. intermedia, and Lauroia trinidadensis in the shape of cephalic cap, alae extension (longer in L. bolivari), and proportion of spicules (unequal in L. bolivari).

Lauroia bolivari and its congeners are the only heterakine nematodes having neither a rim nor a gubernaculum. Species included in Lauroia are characterized by possessing a cephalic cap with 3 simple shields and a tail with few and relatively inconspicuous papillae (Fig. 6).

At present, the genus comprises L. travassosi Proença, 1938, L. trinidadensis Cameron, 1939, L. intermedia Caballero, 1955, and L. dasypi Flores-Barroeta, 1956. Hitherto, all species had been exclusively recorded from $D$. novemcinctus throughout most of its range except $L$. travassosi, which also was found in E. sexcinctus (Proença, 1938). They all occur in the ceca and large intestines of armadillos collected in Brazil, Trinidad, Guatemala, and Mexico (Proença, 1938; Cameron, 1939; Caballero, 1955; Flores-Barroeta, 1956).

Cameron (1939) differentiated L. trinidadensis from L. travassosi because the latter has posterior appendages in the cephalic plates and the former does not (Figs. 2, 10). Among the species described in Lauroia, L. trinidadensis, L. dasypi, and $L$. intermedia are similar to each other both in the structure of the hood and in the shape of the cephalic plates. They have no posterior appendage, and there is a groove that slightly separates the hood from the body (Figs. 10, 11). In contrast, $L$. travassossi and L. bolivari have an umbrellalike hood, and the posterior part of the cephalic plates seem to be wider than the body (Fig. 12). The posterior appendages on the lateroventral plates of the hood seem to be the tissue that joins the plate with the body (Figs. 2, 12).

Regarding distribution patterns, L. trinidadensis, L. intermedia, and L. dasypi occur in localities north of the Amazon basin (Trinidad, Guatemala, and Veracruz, respectively), and L. travassosi and $L$. bolivari occur in localities south of the same basin (Minas Gerais, Brazil, and El Beni, Bolivia, respectively).

This coincidence in the structure of the head and the spatial distribution of all the species may be the result of the split of an ancestral species resulting in 2 possible sister lineages. If such a hypothesis is supported by a phylogenetic analysis of the family, a split of the genus into 2 genera may be justified.

Lauroia bolivari $\mathrm{n}$. sp. is also the second species of this genus recorded from continental South America. Previously, the genus was represented only by L. travassosi occurring in eastern Brazil (Proença, 1938), suggesting that the diversity of species in the genus may be higher than previously recognized.

Chabaud (1978) considered the monotypic Proencaia Gomes and Pereira, 1970, as a junior synonym of Lauroia because in both genera cordons are lacking and each lip is covered by cuticular shields. Chabaud (1978) also argued that because males of Lauroia possess a "reduced pre-anal sucker" on their ventral surface, the presence of a cuticularized rim in Proencaia was not enough to support the validity of the former genus. Whereas the hypothesis of Chabaud (1978) was valid, based on the knowledge of these nematodes at that time, new evidence shows that Proencaia is not a junior synonym of Lauroia. This is because the presence or absence of a rim on the sucker of these nematodes is a primary diagnostic character for the Heterakoidea; so the presence or absence of this structure must be used to separate Proencaia from Lauroia.

\section{DISCUSSION}

Aspidodera binansata was previously recorded in Bolivia by Sprhen (1932). Aspidodera binansata is a species with a wide distribution on the eastern part of the continent and the Caribbean islands ranging from Paraguay to Trinidad (Cameron, 1939; Cameron and Reesal, 1951; Santos et al., 1990). The species often occurs in sympatry with $A$. fasciata and less frequently with other species of the genus such as Aspidodera scoleciformis. In recent times Fujita et al. (1995) proposed A. esperanzae Fujita, Abe, Oku, Sanabria, Inchaustti, and Kamiya, 1995, as a new species occurring in armadillos in Paraguay. They proposed the 7 "cervical cords and recurrent branches" present in the cephalic cap as the diagnostic trait. These structures are arranged as 2 loops on each side of the lateroventral labia (Fig. 13) and 3 loops on the surface of the dorsal labium (Fig. 11). This arrangement is 1 loop anteriad on the surface of the lateroventral lips and 2 loops anteriad on the surface of the dorsal lip (see also figs. 2, 3 in Fujita et al., 1995).

The species name binansata appears to be composed of the Latin words bi (2), nano (small), and ansatus (having handles). The species name describes the possession of 2 small handles 

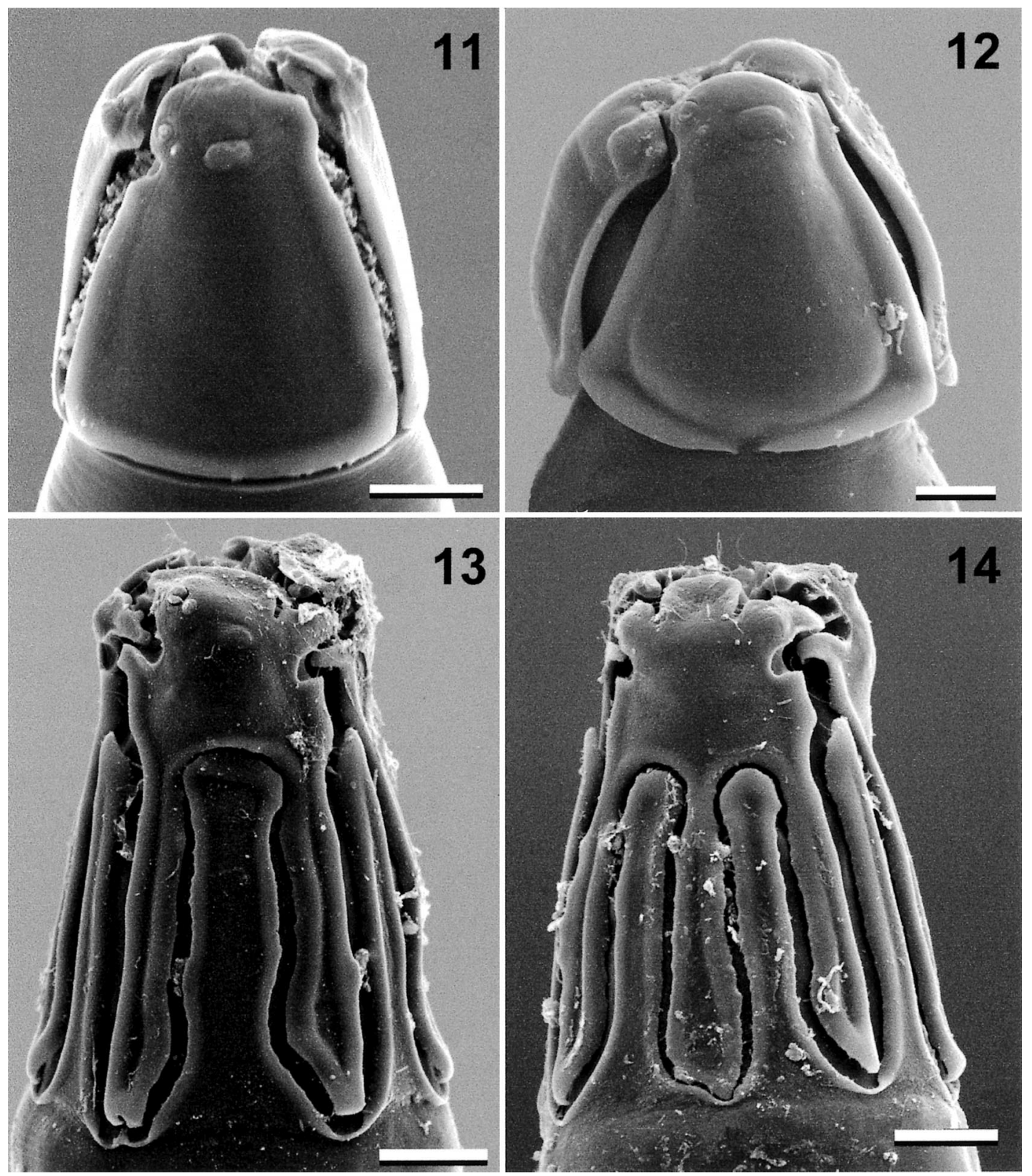

FIgURES 11-14. External structure of the hood of species of Aspidoderidae. 11-12. Hood and dextral lip of 2 species in Lauroia. 11. Lauroia

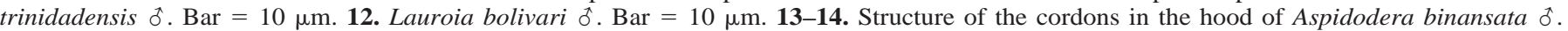
13. Dextral lip showing the 1 anteriad and 2 posteriad loops of the cordons. Bar $=10 \mu \mathrm{m}$. 14. Dorsal lip showing the 2 anteriad and 3 posteriad loops of the cordons. Bar $=10 \mu \mathrm{m}$.

in the interlabial spaces (Railliet and Henry, 1912). Nevertheless, after studying specimens from several museums, we found that those specimens have 2 loops directed anteriad (or 3 loops posteriad) on the surface of the dorsal lip (also called the "labial space"). This character is the diagnostic trait for A. esperanzae. Because it also occurs in $A$. binansata, we synonymize A. esperanzae with $A$. binansata in this study.

To contain the species A. binansata, Skrjabin and Schikhobalova (1947 in Skrjabin et al., 1961) proposed Sexansodera Skrjabin and Schikhobalova, 1947, based on the assumption that such a species would have a total of 9 loops forming the cordons. They assumed that on the surface of each lip there would be 3 posteriad oriented loops as seen on the dorsal lip.
However, as stated by Inglis (1967) such is not the case because there is no double loop on any of the lateroventral lips. So, Sexansodera should not be considered valid.

In a later revision of Aspidodera, Santos et al. (1990) proposed that the specimens that Sprhen (1932) identified as $A$. binansata were A. fasciata. We do not agree with this synonymy because the hood of those specimens is typical for A. binansata. The structure of the cephalic cap is very important in the taxonomy of members of the family (Inglis, 1957), and it is the most reliable character to differentiate between A. fasciata and A. binansata. Another difference between both species is the spinneret on the tail of both species; this structure is needle shaped in A. fasciata and fusiform in A. binansata. Used in 
combination (Santos et al., 1990), the structure of cordons, the shape of spicules, and the shape of the spinneret on a male's tail may be enough to identify species in the genus.

\section{ACKNOWLEDGMENTS}

Both work in the field and writing of this article were supported by National Science Foundation grants BSR 8612329, BSR 9024816, DEB 9496263, DEB 9631295, and DBI 0097019 to S.L.G. We thank Dely Noronha (CHIOC), Eric Hoberg (USNPC), Luis García (CNHE), and Ganzorig Sumiya (CPSVM) for providing us the material that they have under their care. Special thanks to Claudia Flores, Brian Frank, Jon Dunnum, Jerry Dragoo, Jesús Martínez, Jorge Salazar-Bravo, and Julieta Vargas for their help in the field. F.A.J.-R. acknowledges support provided by CONACyT-México in the form of a scholarship and both the Walker Graduate Student Funds and the Initiative in Ecology and Evolutionary Biology granted by the School of Biological Sciences of the University of Nebraska-Lincoln.

\section{LITERATURE CITED}

Albinger, G., A. Fontes Jr., K. Kerle, N. Link, A. Macy, and S. Simon. 1995. SigmaScan Pro. Jandel Scientific Software, San Rafael, California.

ANDERsOn, S. 1997. Mammals of Bolivia: Taxonomy and distribution. Bulletin of the American Museum of Natural History 231: 1-652.

CABAllero, E. 1955. Estudios helmintologicos de la región oncocercosa de México y de la república de Guatemala. Nematoda. 9a parte. Acta Zoológica Mexicana 1: 1-5.

CAmeron, T. W. M. 1939. Studies on the endoparasitic fauna of Trinidad mammals. VI. Parasites of edentates. Canadian Journal of Research 17: $249-264$.

, AND M. R. Reesal. 1951. Studies on the endoparasitic fauna of Trinidad mammals. VII. Parasites of hystricomorph rodents. Canadian Journal of Zoology 29: 276-289.

Chabaud, A. G. 1978. Keys to genera of the superfamilies Cosmocercoidea, Seuratoidea, Heterakoidea and Subuluroidea. Commonwealth Agricultural Bureaux International, Farnham Royal, U.K., p. 71 .

Flores-Barroeta, L. 1956. Nemátodos de aves y mamíferos I. Acta Zoologica Mexicana 1: 1-9.

Freitas, J. F. T. 1956. Notas sôbre "Heterakidae" Railliet \& Henry, 1914 (Nematoda, Subuluroidea). Revista Brasileira de Biologia 16: 461-482.

Frey, J. K., D. W. Duszynski, W. L. Gannon, T. L. Yates, and S. L. GARDNER. 1992. Designation and curation of type host specimens (symbiotypes) for new parasite species. Journal of Parasitology 78: 930-932.

Fujtta, O., N. Abe, Y. Oku, L. Sanabria, A. Inchaustti, and M. KaMIYA. 1995. Nematodes of armadillos in Paraguay: A description of a new species Aspidodera esperanzae (Nematoda: Aspidoderidae). Journal of Parasitology 81: 936-941.

Gardner, S. L. 1991. Phyletic coevolution between subterranean rodents of the genus Ctenomys (Rodentia: Hystricognathi) and nematodes of the genus Paraspidodera (Heterakoidea: Aspidoderidae) in the Neotropics: Temporal and evolutionary implications. Zoological Journal of the Linnean Society 102: 169-201.

Gomes, D. C., AND R. C. S. Pereira. 1970. Sôbre um nôvo gênero da família "Lauroiinae" Skrjanin \& Shikhobalova, 1951 (Nematoda, Subuluroidea). Atas da Sociedade Biologica do Rio de Janeiro 12: $35-37$.

INGLIS, W. G. 1957. The comparative anatomy and systematic significance of the head in the nematode family Heterakidae. Proceedings of the Zoological Society of London 128: 133-143.

. 1967. The evolution, host relationships and classification of the nematode superfamily Heterakoidea. Bulletin of the British Museum (Natural History) 15: 3-28.

Proença, M. C. 1937. Revisâo do genero Aspidodera Railliet and Henry, 1912. Memórias do Instituto Oswaldo Cruz 32: 427-438.

. 1938. Sobre um novo tipo de Heterakinae Railliet et Henry, 1912 (Nematoda: Subuluroidea). In Livro Jubilar Professor Travassos, vol. 3, Instituto Oswaldo Cruz, Rio de Janeiro, Brazil, p. 419420.

Railliet, A., AND A. Henry. 1912. Quelques nématodes parasites des reptiles. Bulletin de la Societé de Pathologie Exothique 5: 251259.

Santos, C. P., H. Lent, And D. C. Gomes. 1990. The genus Aspidodera Railliet and Henry, 1912 (Nematoda: Heterakoidea): Revision, new synonyms and key for species. Revista Brasileira do Biologia 50: $1017-1031$

Skrjabin, K. I., N. P. Shikhobalova, and E. A. Lagodovskaya. 1961. Osnovy Nematodologii Tom X. Oksiurati zhivotnikh i cheloveka. Chast 2. Izdatel'stvo Akademiya Nauk SSSR, Moskva, U.S.S.R., $499 \mathrm{p}$.

SOKAL, R. R., AND F. J. Rohlf. 1981. Biometry, 2nd ed. W. H. Freeman and Co., New York, New York, p. 859.

SpReHN, C. 1932. Über einige von Dr. Eisentraut in Bolivien gesammelte Nematoden. Zoologischer Anzeiger 100: 273-284.

Sutton, C. A., A. G. Chabaud, and M. C. Durette-Desset. 1980. Contribución al conocimiento de la fauna parasitológica argentina. VI. Sobre un nuevo Lauroiinae (Nematoda, Ascaridida). Bulletin du Muséum national D'Histoire naturelle, Paris, $4^{\mathrm{e}}$ srie 2: 81-85. 